\title{
Presence of methyl sterol and bacteriohopanepolyol in an outer-membrane preparation from Methylococcus capsulatus (Bath)
}

\author{
Linda L. Jahnke, ${ }^{*}$ Helga Stan-Lotter, ${ }^{1}$ Katharine Kato and Lawrence I. Hochstein \\ NASA-Ames Research Center, Moffett Field, California 94035, USA \\ ${ }^{1}$ Institute of Microbiology and Genetics, University of Vienna, Vienna, Austria
}

(Received 27 January 1992; revised 8 April 1992; accepted 21 April 1992)

\begin{abstract}
Cytoplasmic/intracytoplasmic and outer membrane preparations of Methylococcus capsulatus (Bath) were isolated by sucrose density gradient centrifugation of a total membrane fraction prepared by disruption using a French pressure cell. The cytoplasmic and/or intracytoplasmic membrane fraction consisted of two distinct bands, Ia and Ib (buoyant densities 1.16 and $1.18 \mathrm{~g} \mathrm{ml}^{-1}$, respectively) that together contained $57 \%$ of the protein, $68 \%$ of the phospholipid, $73 \%$ of the ubiquinone and $89 \%$ of the $\mathrm{CN}$-sensitive NADH oxidase activity. The only apparent difference between these two cytoplasmic bands was a much higher phospholipid content for Ia. The outer membrane fraction (buoyant density $1.23-1.24 \mathrm{~g} \mathrm{ml}^{-1}$ ) contained $60 \%$ of the lipopolysaccharide-associated, $\beta$ hydroxypalmitic acid, $74 \%$ of the methylsterol, and $66 \%$ of the bacteriohopanepolyol (BHP); phospholipid to methyl sterol or BHP ratios were 6: 1 . Methanol dehydrogenase activity and a $c$-type cytochrome were also present in this outer membrane fraction. Phospholipase $A$ activity was present in both the cytoplasmic membrane and outer membrane fractions. The unique distribution of cyclic triterpenes may reflect a specific role in conferring outer membrane stability in this methanotrophic bacterium.
\end{abstract}

\section{Introduction}

Methanotrophs are Gram-negative bacteria capable of growth on methane as their sole source of carbon and energy. Electron micrographs reveal not only the presence of an outer and an inner (cytoplasmic) membrane, but additionally a complex internal (intracytoplasmic) membrane system (Davies \& Whittenbury, 1970). Analysis of the lipid extracts of intact cells demonstrated the presence of a group of membrane lipids, the hopanoids, in all methanotrophic bacteria (Rohmer et al., 1984). The principal hopanoid in methanotrophs is an amphiphilic molecule consisting of a pentacyclic triterpene nucleus linked to a polyhydroxylated side chain referred to as bacteriohopanepolyol (BHP). Some evidence suggests that these molecules function as membrane stabilizers in much the same manner as sterols do in eukaryotes (Ourisson et al., 1987). The synthesis of hopanoids is considered to have evolved prior to sterols because of the widespread distribution of

\footnotetext{
* Author for correspondence. Tel. (415) 6043221 ; fax (415) 6041088.
}

Abbreviations: BHP, bacteriohopanepolyol; KDO, 2-keto-3deoxyoctonate. hopanoids amoung prokaryotes, and because sterol synthesis requires oxygen and hopanoid synthesis does not. Indeed, hopanoids have been proposed as the phylogenetic precursors of the eukaryotic steroids (Rohmer et al., 1979).

The synthesis of cyclic triterpenes in $M$. capsulatus is of particular evolutionary interest, because it is the only known bacterium to synthesize large amounts of both hopanoids and sterols (Ourisson et al., 1987). This bacterium can cyclize squalene to diploptene and 2,3epoxysqualene to lanosterol (Rohmer et al., 1980). In $M$. capsulatus, the primary hopanoid product is a BHP molecule with an aminopentol side chain (Neunlist \& Rohmer, 1985), and the primary sterol products are 4,4dimethyl and $4 \alpha$-methyl sterols (Bird et al., 1971). These methyl sterols are the products of the incomplete demethylation of lanosterol and represent only the initial enzymic steps of the $\mathrm{C}_{27}$ sterol pathway that results in the synthesis of cholesterol in many eukaryotes (Bloch, 1983).

Few data are available on the lipid composition of isolated membranes in methanotrophs, particularly with regard to the cyclic triterpenes. Separation of the outer and cytoplasmic/intracytoplasmic membranes has been attempted for Methylomonas methanica, but no lipid 
analysis was reported (Chemina \& Trotsenko, 1981). Some preliminary, qualitative evidence suggests that the BHP of a facultative methanotroph, Methylobacterium organophilum, is present in the isolated membranes (Hancock \& Williams, 1986). The presence of such unusual lipids in methanotrophic membranes poses many interesting questions about their relationship to the physiology of these bacteria and the evolution of membrane function. As a first effort to understand their role, we have attempted to separate the inner (cytoplasmic and/or intracytoplasmic) and outer membranes of $M$. capsulatus, and have isolated an outer membrane fraction highly enriched in both BHP and methyl sterols.

\section{Methods}

Organism and growth conditions. Methylococcus capsulatus (Bath) was obtained from the American Type Culture Collection (ATCC 33009). Bacteria were grown at $37^{\circ} \mathrm{C}$ in 5.51 defined nitrate mineral salts medium containing $10 \mu \mathrm{g} \mathrm{CuCl}_{2} \mathrm{l}^{-1}$ with a continuous stream $(100 \mathrm{ml}$ $\mathrm{min}^{-1}$ ) of methane/air/ $\mathrm{CO}_{2}(49: 49: 2)$ as previously described (Jahnke \& Nichols, 1986).

Membrane preparation. All procedures were performed at $4{ }^{\circ} \mathrm{C}$. Bacteria were harvested by centrifugation at $6000 \mathrm{~g}$ for $10 \mathrm{~min}$. Cells (4-5 $\mathrm{g}$ wet $\mathrm{wt}$ ) were washed once with distilled water, suspended in water, and treated with a Sorvall Omnimixer blender to remove capsular material (Schnaitman, 1970). Cells were recovered by centrifugation and suspended to $20 \mathrm{ml}$ with $20 \mathrm{mM}$-HEPES buffer (Research Organics) (pH 7.4). When methanol dehydrogenase was to be analysed, the buffer was made $10 \mathrm{~mm}$ with respect to methanol prior to cell breakage (Ghosh \& Quayle, 1981). Approximately $1 \mathrm{mg}$ each of pancreatic ribonuclease and deoxyribonuclease were added to the suspension, and the cells were broken by one passage through an Aminco French pressure cell operated at $103 \mathrm{MPa}$. The broken cell suspension was centrifuged twice at $6000 \mathrm{~g}$ for $10 \mathrm{~min}$ to remove whole cells and debris. The supernatant (SII) was centrifuged for $60 \mathrm{~min}$ at $197000 \mathrm{~g}$. The resultant pellet (TM) was suspended with HEPES buffer containing $34 \%(\mathrm{w} / \mathrm{w})$ sucrose and was applied to the top a $28 \mathrm{ml}$, $35 \%$ to $55 \%(\mathrm{w} / \mathrm{w})$ continuous sucrose gradient. Samples were centrifuged in a Beckman SW27 rotor at 25000 r.p.m. for 16 h. The four observed bands were collected by immersing a 15-gauge cannula through the gradient and withdrawing fractions from the bottom by means of a peristaltic pump. Sucrose density was determined with a refractometer. The fractions containing individual bands were pooled, and the sucrose was diluted at least two-fold with HEPES buffer containing $\mathrm{NaCl}$ (final concentration adjusted to $50 \mathrm{mM}$ ), then centrifuged for $60 \mathrm{~min}$ at $200000 \mathrm{~g}$. The resulting pellets were rinsed with, then suspended in, a small amount of HEPES buffer. Phospholipase and NADH oxidase assays, and lipid extraction were done with freshly prepared material; samples were frozen at $-20^{\circ} \mathrm{C}$ for methanol dehydrogenase, protein and cytochrome analyses. In some experiments designed to minimize the potential for membrane hybridization, the total membrane fraction for application to the continuous sucrose gradients was prepared by breaking cells using a HEPES buffer containing $20 \%$ sucrose, and then preparing the crude membranes by the discontinuous gradient method of Ishidate $e t$ al. (1986).

Lipid extraction, separation, and analysis. Lipids were extracted from the freshly prepared membrane fractions with a one-phase Bligh \&
Dyer (1959) extraction as modified by Kates (1986). The residue was recovered by centrifugation before initiating phase separation and was used for $\beta$-hydroxy fatty acid analysis (see below). The total lipid extract was analysed for phospholipid phosphate (Dittmer \& Wells, 1969), and phospholipid esterified fatty acid by mild-alkaline methanolysis (White et al., 1979). Polar (phospholipid and BHP) and neutral (sterol and ubiquinone) lipids were separated by precipitation of the polar lipids in cold acetone (Summons \& Jahnke, 1992). The BHP was recovered by Bligh \& Dyer (1959) extraction of the acetone precipitate and was converted to its hopanol derivative according to procedure II of Rohmer et al. (1984). Neutral lipids were further separated on silica gel $\mathrm{G}$ thin-layer plates (Merck) developed to a height of $15 \mathrm{~cm}$ twice with methylene chloride in a paper-lined tank. The $4 \alpha$-methyl and 4,4dimethyl sterols $\left(R_{F} \mathbf{0 . 2 1}\right.$ and 0.25 , respectively) were recovered and analysed as previously described (Jahnke \& Nichols, 1986). The ubiquinone (Q-8), which was an intense yellow band $\left(R_{F} 0 \cdot 73\right)$, was recovered from the silica gel by elution with chloroform, and identified by its ultraviolet absorption spectrum in absolute ethanol (Crane \& Barr, 1971), and its behaviour on Whatman KC18 reverse-phase thinlayer plates (Collins, 1985). Quantification of the ubiquinone was based on an oxidized minus borohydride reduced extinction coefficient at $275 \mathrm{~nm}$ of $\Delta \varepsilon_{\mathrm{mM}}=12.7$ (Crane \& Barr, 1971).

Lipopolysaccharide content. The lipopolysaccharide (LPS) content of TM was determined by analysis of the 2-keto-3-deoxyoctonate (KDO) and $\beta$-hydroxy fatty acids. KDO was measured by the method of Karkhanis et al. (1978) using a lyophilized TM preparation. The $\beta$ hydroxy fatty acids were analysed using the solvent-extracted membrane residue by the method of Nichols et al. (1987). Methyl esters of the hydroxy fatty acids were prepared using boron trifluoridemethanol (O'Brien \& Rouser, 1964). The methylated $\beta$-hydroxy fatty acids were isolated by TLC $\left(R_{F}, 0.22\right)$ in the above $\mathrm{CH}_{2} \mathrm{Cl}_{2}-\mathrm{TLC}$ system, and analysed by gas chromatography. Hydroxy fatty acid identification was based on comparison of relative TLC mobility and GC retention times with data for standards obtained from Supelco and Ultra Scientific.

Gas chromatographic analysis. Normal and hydroxy fatty acids, methyl sterols and BHP hopanol derivatives were analysed on a Perkin-Elmer Sigma 3B gas chromatograph equipped with a flame ionization detector and fused silica megabore columns $(\mathrm{J} \& \mathrm{~W}$ Scientific). Methylated fatty acids were separated on a $30 \mathrm{~m}$ DB-23 operated at $155^{\circ} \mathrm{C}$. Acetates of the methyl sterols and the hopanols were prepared (Jahnke \& Nichols, 1986) and were separated on a $30 \mathrm{~m}$ DB-5 operated at $295^{\circ} \mathrm{C}$. Quantification of methyl sterol, $\beta$-OH palmitate and phospholipid fatty acids was based on recovery of internal standards [ $\beta$-cholestanol, $\beta$-OH myristate and (diarachidoyl)phosphatidylcholine, respectively].

Enzyme assays. NADH oxidase activity was measured at $22^{\circ} \mathrm{C}$ in the presence and absence of $10 \mathrm{mM}-\mathrm{KCN}$ by recording the decrease in absorbance at $340 \mathrm{~nm}$ in incubation mixtures containing $120 \mu \mathrm{M}$ NADH, 20 mM-HEPES (pH 7.4) and membrane fraction. Methanol dehydrogenase was measured as described by Ghosh \& Quayle (1981). Phospholipase activity was measured as the decrease in esterified fatty acid over $20 \mathrm{~min}$ at $37^{\circ} \mathrm{C}$. The substrate, endogenous phospholipid, was prepared by heating a crude membrane fraction at $90^{\circ} \mathrm{C}$ for $5 \mathrm{~min}$. Incubation mixtures contained this crude phospholipid (approximately $6 \mu \mathrm{mol}$ esterified fatty acid), $100 \mu \mathrm{g}$ Triton $\mathrm{X}-100,75 \mathrm{mM}-\mathrm{CaCl}_{2}$, $20 \mathrm{mM}$-HEPES (pH 7.4) and membrane fraction in $1 \mathrm{ml}$. Incubations were stopped at zero, $10 \mathrm{~min}$ and $20 \mathrm{~min}$ intervals by addition of methanol/chloroform. An internal standard (diarachidoyl)phosphatidylcholine, was added, the phospholipid was extracted, and the amount of esterified fatty acid was determined by the mild-alkaline methanolysis procedure of White et al. (1979). 
Gel electrophoresis. The polypeptide composition of the isolated membrane fractions was analysed by SDS-PAGE on $12 \%(\mathrm{w} / \mathrm{v})$ gels, $0.75 \mathrm{~mm}$ thick, in a discontinuous buffer system (Laemmli, 1970) at a constant $45 \mathrm{~mA}$, with water cooling. The gels were stained for protein with Coomassie Brillant Blue R. Low-molecular-mass markers (Dalton VII-L, Sigma) were used as standards. Membrane proteins were solubilized by heating at $100{ }^{\circ} \mathrm{C}$ for $3 \mathrm{~min}$ in $1 \%$ (w/v) SDS sample buffer (Laemmli, 1970).

Cytochrome spectra. Cytochrome spectra of the isolated membrane fractions were measured at room temperature in an Aminco DW2A dual wavelength/split-beam spectrophotometer operated in the split beam mode. Reduced minus oxidized spectra were obtained by reducing one cuvette with a few grains of $\mathrm{Na}_{2} \mathrm{~S}_{2} \mathrm{O}_{4}$. Reduced plus $\mathrm{CO}$ minus reduced spectra were obtained by reducing both cuvettes with $\mathrm{Na}_{2} \mathrm{~S}_{2} \mathrm{O}_{4}$, and bubbling a steady stream of $\mathrm{CO}$ through one cuvette for $30 \mathrm{~s}$. The CO-treated cuvette was left in the dark for $15 \mathrm{~min}$ before recording the spectra.

Electron microscopy. Pellets of the isolated membrane fractions were fixed at $4{ }^{\circ} \mathrm{C}$ with $0.5 \% \mathrm{OsO}_{4}$ for $30 \mathrm{~min}$, or with $2 \%(\mathrm{w} / \mathrm{v})$ glutaraldehyde for $30 \mathrm{~min}$, followed by $0.5 \% \mathrm{OsO}_{4}$ plus $0.8 \%$ $\mathrm{K}_{3} \mathrm{Fe}(\mathrm{CN})_{6}$ for $30 \mathrm{~min}$ (McDonald, 1984). Both fixation procedures were followed by en bloc staining with $2 \%(\mathrm{w} / \mathrm{v})$ aqueous uranyl acetate for $2 \mathrm{~h}$ at $4{ }^{\circ} \mathrm{C}$. Reagents were prepared in 0.02 M-HEPES ( $\mathrm{pH} \mathrm{7.4)}$ ). Samples were dehydrated in increasing concentrations of ethanol, followed by butyl glycidyl ether, then embedded in Quetol 651. Sections were stained with uranyl acetate-lead citrate and examined in a Philips 300 electron microscope.

Protein was determined by the bicinchoninic acid procedure using bovine albumin as the standard (Smith et al., 1985).

\section{Results}

Separation and characterization of membrane fractions

Centrifugation of TM on continuous sucrose density gradients resulted in four visible bands. The upper two bands, designated $\mathrm{Ia}$ and $\mathrm{Ib}$, had buoyant densities of 1.16 and $1.18 \mathrm{~g} \mathrm{ml}^{-1}$, respectively. Centrifugation of bands Ia or Ib yielded a pellet that was straw-coloured upon suspension. The bottom band, III, was considerably broader, ranging from a buoyant density of 1.23 to $1.24 \mathrm{~g} \mathrm{ml}^{-1}$, and yielded a membranous material with a distinct pinkish coloration. Band II had an intermediate density $\left(1.21 \mathrm{~g} \mathrm{ml}^{-1}\right)$ and had a similar pinkish coloration.

Analysis of the TM fraction $(197000 \mathrm{~g}$ pellet $)$ yielded almost equimolar amounts of KDO and $\beta$-hydroxypalmitic acid. Hydroxy fatty acids have been reported to be associated with LPS isolated from $M$. organophilum (Hancock \& Williams, 1986), and in methanotrophs, such as $M$. capsulatus, $\beta-\mathrm{OH}$ palmitic acid is the predominant acid found (Nichols et al., 1985; Bowman et al., 1991). Because of our requirement in these experiments for large amounts of material for lipid analyses, it was convenient to use the lipid-extracted residue for $\beta$-OH fatty acid analysis as a marker for the outer membrane. In our experiments, virtually all of the $\beta$-hydroxy acid was palmitic, only a small amount of $\beta$ hydroxymyristate $(0.5 \%$ of the total) was detected in the absence of added internal standard.

The results of the chemical and enzyme analyses on the isolated membrane fractions are shown in Table 1. $\beta$ Hydroxy fatty acid and ubiquinone were used routinely as indicators for the outer and cytoplasmic membranes, respectively. In four experiments, Ia and $\mathrm{Ib}$ together accounted for $77 \pm 3 \%$ of the ubiquinone. This observation, coupled with the presence of cyanidesensitive NADH oxidase activity and with the relatively small amounts of $\beta$-hydroxy fatty acid, suggest that the

Table 1. Chemical composition and enzyme activities of isolated membrane fractions from $M$. capsulatus

Data reported are for the total membrane material recovered by centrifugation of gradient fractions and its relative distribution. Recovery of applied TM material was $76 \%$ or greater with the exception of protein $(56 \%)$ and methanol dehydrogenase $(67 \%)$. Results are means of three experiments.

\begin{tabular}{|c|c|c|c|c|c|}
\hline \multirow[b]{2}{*}{ Component } & \multirow{2}{*}{$\begin{array}{c}\text { Total } \\
\text { Recovery }\end{array}$} & \multicolumn{4}{|c|}{ Distribution $(\%)$} \\
\hline & & Ia & Ib & II & III \\
\hline Protein & $40 \cdot 3^{*}$ & 25 & 32 & 16 & 27 \\
\hline Phospholipid & $17 \cdot 7 \dagger$ & 39 & 29 & 16 & 17 \\
\hline Phospholipase & $5 \cdot 2 \ddagger$ & 16 & 27 & 27 & 30 \\
\hline Ubiquinone & $0 \cdot 4 \dagger$ & 37 & 36 & 18 & 9 \\
\hline NADH oxidase ( $C N$ sensitive) & $0.8 \ddagger$ & 47 & 42 & 8 & 3 \\
\hline$\beta$-Hydroxy fatty acid & $1 \cdot 3 \dagger$ & 3 & 8 & 29 & 60 \\
\hline Methanol dehydrogenase & $11 \cdot 3 \ddagger$ & 7 & 9 & 41 & 42 \\
\hline
\end{tabular}

* Total recovered protein expressed in $\mathrm{mg}$.

+ Total recovered material expressed in $\mu \mathrm{mol}$.

$\ddagger$ Total recovered activity expressed in $\mu$ mol product $\min ^{-1}$. 


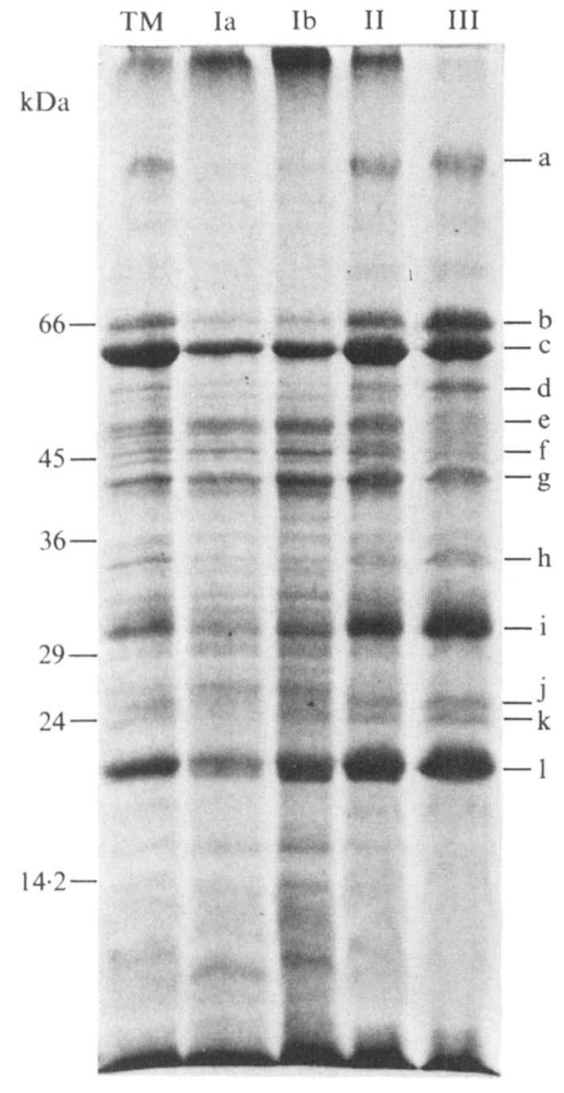

Fig. 1. SDS-PAGE of the membrane fractions. Total membranes from a $200000 \mathrm{~g}$ pellet (TM), and isolated membranes from four visible bands (Ia, Ib, II \& III) on sucrose density gradients. Each sample contained $20 \mu \mathrm{g}$ protein. Molecular mass markers $(\mathrm{kDa})$ are shown on left.

material recovered from bands Ia and Ib represents the cytoplasmic and/or intracytoplasmic membrane(s). In contrast, band III contained most of the $\beta$-hydroxy fatty acid, suggesting the presence of the outer membrane. Both the methyl sterol and BHP showed a distribution similar to that of $\beta$-hydroxy fatty acid (Table 2).

The distribution of membrane components between the low density (Ia $+\mathrm{Ib}$ ) and high density (III) membranes was highly reproducible. Some variation was observed in the distribution of the low density material between $\mathrm{Ia}$ and $\mathrm{Ib}$; however, Ia consistently contained higher levels of phospholipid than Ib. Based on a molecular mass of $692 \mathrm{Da}$ for the major phospholipid in $M$. capsulatus (dipalmitoyl)phosphatidylethanolamine (Makula, 1978), the phospholipid content of Ia would be $0.49 \pm 0.05 \mathrm{mg}$ (mg protein $)^{-1}$ as compared to a value of $0.24 \pm 0.06$ for Ib and $0.24 \pm 0.03$ for III $(n=3)$.

The material recovered in band II appeared to be a mixture of the membrane material present in bands I and III based on the biochemical characteristics in Table 1
Table 2. Lipid composition of isolated membrane fractions

The results are from an experiment in which band II was not observed, but the lipid data were similar in four experiments. Data are presented as nanomoles of membrane lipid recovered by centrifugation of the designated gradient fraction. Recovery of the phospholipid, methyl sterol and BHP applied to gradients was $74 \%, 100 \%$ and $94 \%$, respectively.

\begin{tabular}{lccc}
\hline \hline & \multicolumn{3}{c}{ Composition } \\
\cline { 2 - 4 } Component & Ia & Ib & III \\
\hline Protein* & $8 \cdot 4$ & $11 \cdot 9$ & $14 \cdot 5$ \\
Phospholipid & 5300 & 3030 & 4530 \\
Ubiquinone & 165 & 177 & 57 \\
$\beta$-Hydroxy fatty acid & 110 & 75 & 970 \\
Methyl sterol & 141 & 136 & 809 \\
Bacteriohopanepolyol & 225 & 135 & 712 \\
\hline \hline
\end{tabular}

* Total recovered protein expressed in mg.

and the SDS-PAGE analysis of membrane proteins (Fig. 1). The amount of material recovered in II varied widely between experiments; in some, band II was not observed, and in others it accounted for as much as $40 \%$ of the total recovered protein and phospholipid. A substantial increase in band II resulted when cells were ruptured by a second passage through the French pressure cell. Preparation of the total membrane material using discontinuous gradients, which are reported to decrease non-specific membrane adhesion (Ishidate et al., 1986), had no effect on the presence of this band in continuous gradients.

Phospholipase activity, which is normally associated with the outer membrane in Gram-negative bacteria, was found in both the upper (Ia and Ib) and lower (III) bands in this organism (Table 1). This phospholipase activity was lost upon freezing; storage at $-20^{\circ} \mathrm{C}$ for $4 \mathrm{~d}$ resulted in a decrease of $60 \%$ in the activity associated with Ia and Ib, while essentially no activity remained in III. Endogenous phospholipase activity was not normally a problem in the preparation of these membranes, however, when TM was prepared according to the methods of Ishidate et al. (1986), large amounts of free fatty acids were observed in the neutral lipid fraction.

As in previous reports (Wadzinski \& Ribbons, 1975; Patel \& Felix, 1976), a significant portion of the methanol dehydrogenase in these cells was membranebound. The TM fraction contained $58 \%$ of the methanol dehydrogenase activity present in SII; the remaining activity was recovered in the $197000 \mathrm{~g}$ supernatant. Of the methanol dehydrogenase activity present in TM, $67 \%$ was recovered in the membrane pellets after 
centrifugation of the gradient fractions, a major portion in fraction III (Table 1). In one experiment, an attempt was made to collect the upper and lower zones of band III. The upper $\left(1.23 \mathrm{~g} \mathrm{ml}^{-1}\right)$ portion had a slightly higher specific activity than the lower $\left(1.24 \mathrm{~g} \mathrm{ml}^{-1}\right)$ portion; $441 \mathrm{nmol} \mathrm{min}-1$ (mg protein) $)^{-1}$ versus $285 \mathrm{nmol} \mathrm{min}^{-1}$ (mg protein $)^{-1}$, respectively.

\section{Membrane protein patterns}

The protein composition of the membrane fractions was analysed by SDS-PAGE (Fig. 1). Ia and Ib were indistinguishable from each other and contained a number of distinct proteins (Fig. 1, proteins e and f). Under the conditions employed, a number of similar bands appear in both I and III, however, at least seven bands (Fig. 1, a, b, d, h, i, j and k) appear significantly enriched in fraction III.

\section{Membrane cytochromes}

The predominant species of cytochrome in methanotrophic bacteria are $c$-types having an $\alpha$-peak at $552-553 \mathrm{~nm}$ (Davey \& Mitton, 1973; Tonge et al., 1974). In our experiments, a cytochrome with an $\alpha$-peak at $553 \mathrm{~nm}$ was the major component in the membranes of Ia, Ib and III (Fig. 2a). Based on an extinction coefficient for the $\alpha$ peak of $\Delta \varepsilon=27.6$ (Wood, 1984), $54 \%$ of the membraneassociated cytochrome $c$ was recovered in Ia and $\mathrm{Ib}$, $2.1 \mathrm{nmol}$ (mg protein) $)^{-1}$, and $34 \%$ in III, $2.6 \mathrm{nmol}$ (mg protein) $)^{-1}$. A distinct peak at $604 \mathrm{~nm}$ and a shoulder in the Soret region at $445 \mathrm{~nm}$ in the spectra of Ia and $\mathrm{Ib}$ indicated the presence of an $a a_{3}$-type cytochrome (Chance \& Williams, 1955; Tonge et al., 1974) in this membrane fraction. A slight asymmetry in the $560 \mathrm{~nm}$ region of the $\alpha$-band may also indicate the presence of a small amount of $b$-type cytochrome in Ib. Reduced plus $\mathrm{CO}$ minus reduced difference spectra of both Ib and III (Fig. $2 b$ ) showed a Soret peak at $415 \mathrm{~nm}$ and a trough in the $\alpha$-band region, indicating the presence of a $c$-type, low-spin CO-complex (Wood, 1984). Based on an $\varepsilon(\alpha-$ peak- $\alpha$-trough $)=25(\mathrm{mM} \mathrm{cm})^{-1}$ for a $c_{c o}($ Wood, 1984), $37 \%$ and $12 \%$ of the $c$-type cytochrome in Ib and III, respectively, binds $\mathrm{CO}$.

\section{Electron micrographs}

Thin sections of membrane fractions Ia (Fig. $3 a$ ) and Ib (Fig. $3 b$ ) showed many faintly-stained unit membrane vesicles filled with a darkly stained material. While Ib was dominated by these osmophilic structures, Ia contained many empty, irregular-shaped vesicles and a variety of convoluted, stacked membrane structures
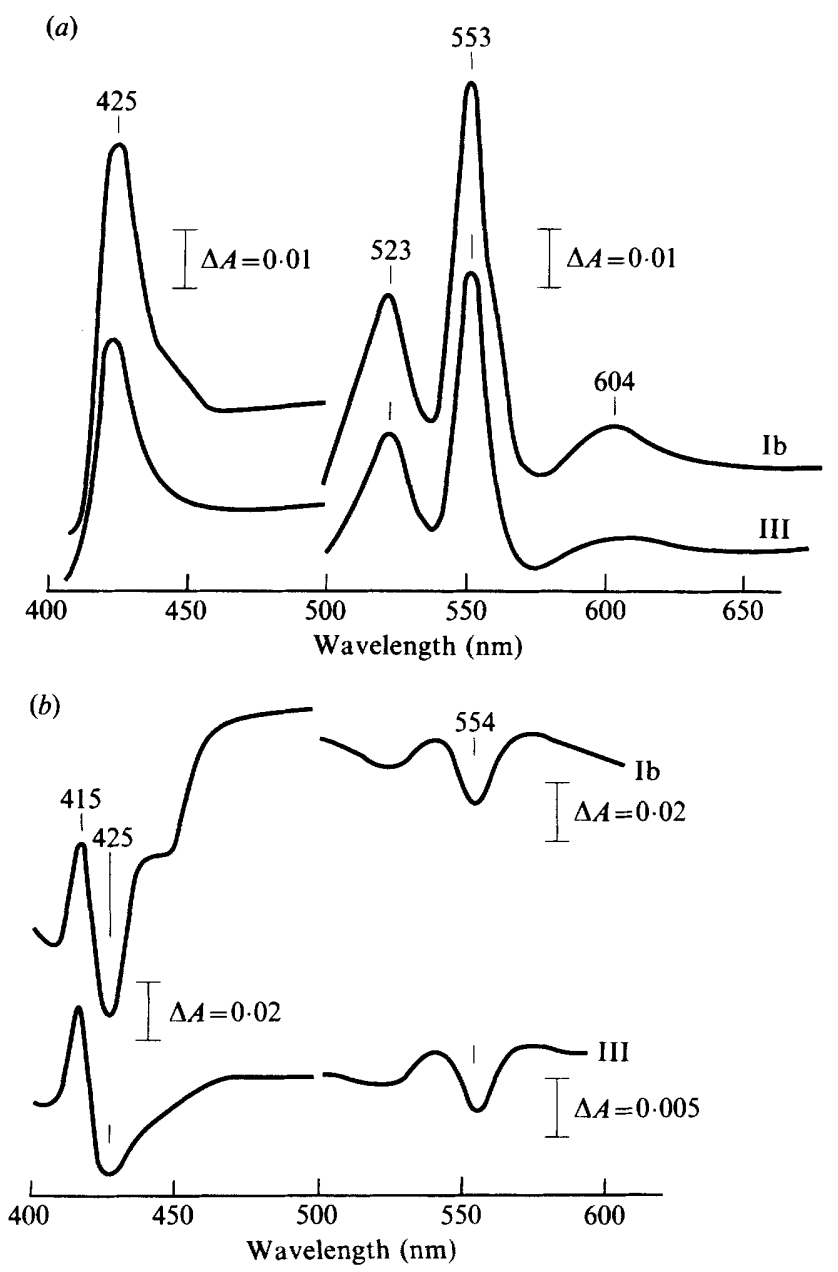

Fig. 2. Absorption spectra of the membrane fractions. (a) $\mathrm{Na}_{2} \mathrm{~S}_{2} \mathrm{O}_{4}$ reduced minus oxidized difference spectra of $\mathrm{Ib}\left(0.9 \mathrm{mg} \mathrm{ml}^{-1}\right)$ and III (0.6 mg ml-1). (b) $\mathrm{Na}_{2} \mathrm{~S}_{2} \mathrm{O}_{4}$-reduced plus $\mathrm{CO}$ minus $\mathrm{Na}_{2} \mathrm{~S}_{2} \mathrm{O}_{4}$-reduced difference spectra of Ib and III.

(Fig. $3 a$, enlargement) which were not apparent in Ib. Thin sections of fraction III (Fig. 3c) showed coiled, Cshape and vesicular structures characteristic of Gramnegative cell wall (Osborn et al., 1972; Ishidate et al., 1986). The darkly-stained double track of the outer membrane and the underlying dense murein layer were clearly present in all fields.

Visualization of the membrane vesicles in Ia or Ib was highly dependent on the fixation method. No membrane structure was observed when glutaraldehyde was used prior to $\mathrm{OsO}_{4}$. We found it was necessary to fix Ia and $\mathrm{Ib}$ directly with $\mathrm{OsO}_{4}$, or when glutaraldehyde was used, to post-fix the membranes with $\mathrm{OsO}_{4} / \mathrm{K}_{3} \mathrm{Fe}(\mathrm{CN})_{6}$ according to the method of McDonald (1984). Fixation method was less critical for preparation of fraction III. 

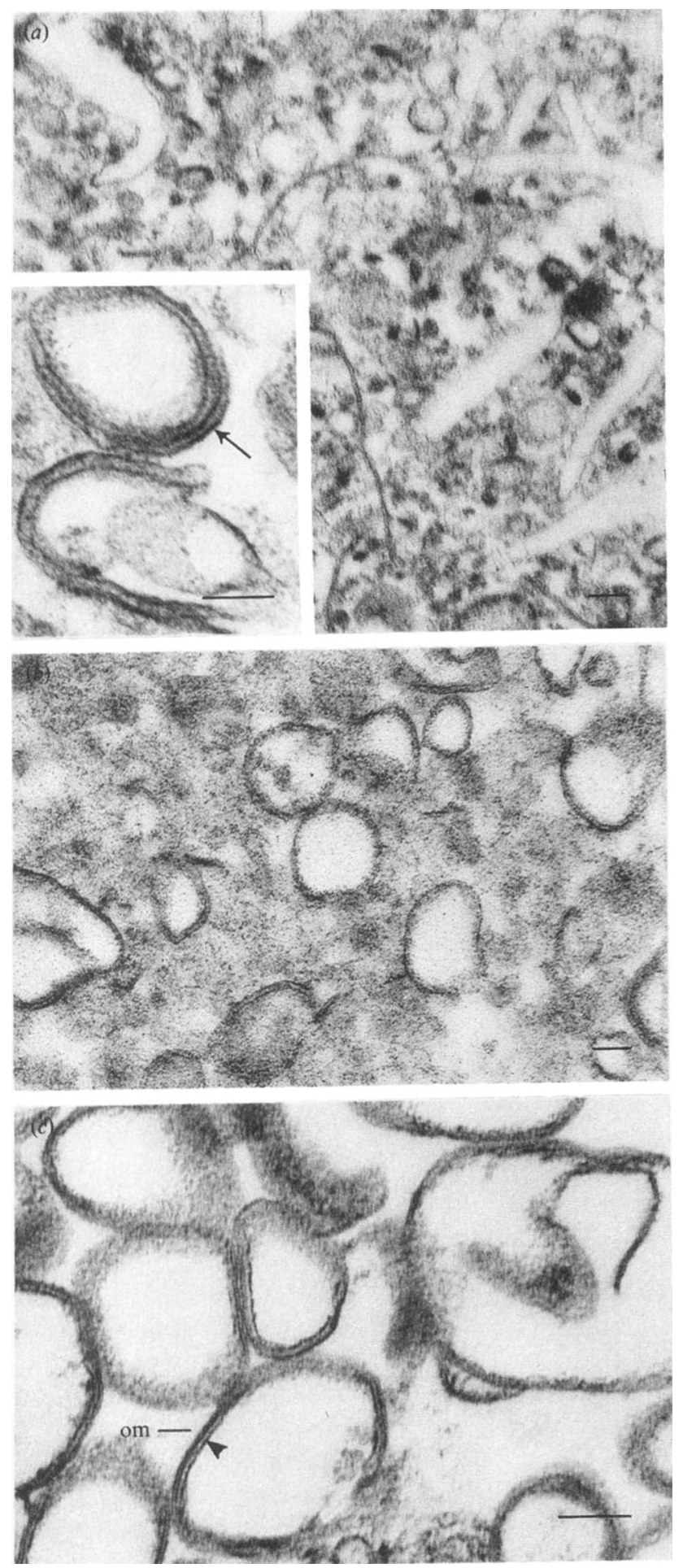

Fig. 3. Electron micrographs of thin sections of membrane fractions. Fraction Ia (a) showing two fields characteristic of this material, one of the irregular-shaped and vesicular structures, and the other (highermagnification insert) of a stacked unit membrane structure (arrow); fraction $\mathrm{Ib}(b)$ showing membrane-bounded, darkly stained material; and fraction III (c) showing outer membrane (om) and underlying murein layer (arrowhead). Pellets were fixed with glutaraldehyde, followed by $\mathrm{OsO}_{4}$ plus $\mathrm{KFe}(\mathrm{CN})_{6}$ as described in text. Bar, $100 \mathrm{~nm}$.

\section{Discussion}

Separation of the cell envelope of $M$. capsulatus by sucrose density gradient centrifugation resulted in isolation of two membrane types that in many respects are similar to the outer and cytoplasmic membranes isolated by Osborn et al. (1972). The two bands of buoyant densities 1.16 and 1.18 (Ia and $\mathrm{Ib}$, respectively) were enriched in a number of electron transport components (cytochrome $a a_{3}$, NADH oxidase and ubiquinone), while band III, buoyant density $1 \cdot 23-1 \cdot 24$, contained most of the LPS-associated $\beta$-hydroxy fatty acids. The SDS-PAGE protein patterns and electron micrographs clearly demonstrate that I and III are unique membrane fractions.

It is well established that phospholipase $A$ is present in the outer membrane of a variety of bacteria (Osborn $e t$ al., 1972; Scott et al., 1976; Booth \& Curtis, 1977); however, in this methanotroph, phospholipase activity was distributed throughout the membrane fractions. The only other report of a similar distribution is in Myxococcus xanthus (Orndorff \& Dworkin, 1980). In $M$. organophilum, a facultative methanotroph, phospholipase A is located in the outer membrane; however, the cells for that study were grown under conditions where intracytoplasmic membrane is not produced (Hancock \& Williams, 1986). Localization of the enzymes responsible for membrane degradation in the intracytoplasmic membrane would be consistent with the high degree of variation observed in the internal membrane morphology of this organism (Hyder et al., 1979; Prior \& Dalton, 1985). Presumably, the rapid turnover involved in the synthesis and degradation of these internal membranes would require an active phospholipase.

Several ultrastructural studies of methanotrophs have shown invaginations of the cytoplasmic membrane seemingly connected to the internal bundles (Davies \& Whittenbury, 1970; DeBoer \& Hazeu, 1972; Saralov et al., 1985). Indeed, Davies \& Whittenbury (1970) have observed in thin sections of disrupted cells that the intracytoplasmic membrane bundles tend to remain in groups accompanied by pieces of cytoplasmic membrane. Localization of the cytochrome oxidase in the intracytoplasmic membrane has been reported based on cytochemical tests (Monosov \& Netrusov, 1976), thus the presence of cyanide-sensitive NADH oxidase and cytochrome $a a_{3}$ in Ia and Ib suggests that some portion of this material represents the intracytoplasmic membrane observed in the electron micrographs of cells grown under these conditions (Jahnke \& Nichols, 1986). The most significant difference between these two upper bands was the higher phospholipid content of Ia, which could reflect the presence of specific membrane domains 
associated with the areas of tight curvature in the internal membrane bundles. This is true of artifical membrane vesicles where the ratio of phospholipid in the outer and inner leaflets is known to be related to the degree of curvature (Cullis \& Hope, 1985), and is also consistent with the highly convoluted membranes apparent in electron micrographs of Ia.

Cytochromes are not normally found in the outer membrane of other Gram-negative bacteria. The presence of cytochrome $c$ in fraction III suggests the presence of some cytoplasmic or pericytoplasmic-associated membrane. The presence of cytochrome in a similar outer membrane preparation from Methylomonas albus has also been observed (personal communication, M. L. P. Collins, University of Wisconsin, Milwaukee, USA). In methylotrophs, methanol dehydrogenase activity is localized in the periplasmic space, where it is thought to function by interaction with cytochrome $c$ on the outer face of the cytoplasmic membrane (Anthony, 1986). The presence of membrane-bound methanol dehydrogenase and cytochrome $c$ in fraction III may merely represent two classes of membrane with similar buoyant densities. Alternatively, it could also be explained by adhesion zones between the outer and cytoplasmic membranes. Such adhesion zones have been documented in Gramnegative bacteria (Bayer, 1979; MacAlister et al., 1983) and have been observed in electron micrographs of methanotrophs (Saralov et al., 1985). A slightly higher specific acitivity for methanol dehydrogenase in the lower density portion of band III does indeed suggest the presence of a subfraction more highly enriched in some such pericytoplasmic membrane fragment.

The enrichment of BHP and methyl sterol in the outer membrane fraction of $M$. capsulatus suggests a specific function for these molecules. Hancock \& Williams (1986) suggested that the exceptional stability of the outer membrane of $M$. organophilum to detergent might be due to the presence of hopanoids; indeed, hopanoids and methyl sterols appear to play a reinforcement role in membranes (Dahl et al., 1980; Benz et al., 1983). Both the hopanoids in Zymomonas mobilis (Bringer et al., 1985) and sterols in yeast (Thomas et al., 1978) have been implicated in the ethanol resistance of these microorganisms. The ratio of phospholipid to either BHP or sterol in fraction III is approximately $6: 1$, and given the nature of the mixture of membrane types in this band, may well be lower in some specific membrane domain. This suggests that both of these cyclic triterpenes are important for the integrity of some outer and/or pericytoplasmic membrane function. Given the hydrophobic nature of a substrate such as methane, the presence of BHP and methyl sterol in the membranes of the cell envelope may relate to the problems commensurate with growth on such a compound.
This work was supported by funding from National Aeronautics and Space Administration's Exobiology program. We would like to thank H. P. Klein and M. L. P. Collins for their helpful suggestions in the preparation of this manuscript.

\section{References}

ANTHONY, C. (1986). Bacterial oxidation of methane and methanol. In Advances in Microbial Physiology, pp.113-210. Edited by A. H. Rose \& D. W. Tempest. London: Academic Press.

BAYER, M. E. (1979). The fusion sites between outer membrane and cytoplasmic membrane of bacteria : their role in membrane assembly and virus infection. In Bacterial Outer Membranes, pp. 167-202. Edited by $\mathbf{M}$. Inouye. New York: John Wiley \& Sons.

Benz, R., Hallmann, D., Poralla, K. \& Eibl, H. (1983). Interaction of hopanoids with phosphatidylcholines containing oleic and $\omega$ cyclohexyldodecanoic acid in lipid bilayer membranes. Chemistry and Physics of Lipids 34, 7-24.

Bird, C. W., LYNCH, J. M., Pirt, S. J., Reid, W. W., Brooks, C. J. W. \& MidDlediTCH, B. S. (1971). Steroids and squalene in Methylococcus capsulatus grown on methane. Nature, London 230, 473-474.

Bligh, E. G. \& DyeR, W. J. (1959). A rapid method of total lipid extraction and purification. Canadian Journal of Biochemical Physio$\log y$ 37, 911-917.

BLOCH, K. (1983). Sterol structure and membrane function. Critical Reviews in Biochemistry 14, 47-92.

Booth, B. R. \& CURTIS, N. A. C. (1977). Separation of the cytoplasmic and outer membrane of Pseudomonas aeruginosa PAO-1. Biochemical and Biophysical Research Communications 74, 1168-1176.

Bowman, J. P., Skerratt, J. H., Nichols, P. D. \& Sly, L. I. (1991). Phospholipid fatty acid and lipopolysaccharide acid signature lipids in methane-utilizing bacteria. FEMS Microbiology Ecology 85, 1522.

Bringer, S. Härtner, T., Poralla, K. \& Sahm, H. (1985). Influence of ethanol on the hopanoid content and the fatty acid pattern in batch and continuous cultures of Zymomonas mobilis. Archives of Microbiology 140, 312-316.

Chance, B. \& Williams, G. R. (1955). Respiratory enzymes in oxidative phosphorylation, II. Difference spectra. Journal of Biological Chemistry 217, 395-407.

Chemina, E. V. \& TrotsenKo, Y. A. (1981). Isolation and identification of Methylomonas methanica membranes. Microbiology 49, 735739.

Collins, M. D. (1985). Isoprenoid quinone analyses in bacterial classification and identification. In Chemical Methods in Bacterial Systematics, pp. 267-287. Edited by M. Goodfellow \& D. E. Minnikin. London: Academic Press.

Crane, F. L. \& BarR, R. (1971). Determination of ubiquinones. Methods in Enzymology 18, 137-165.

Cullis, P. R. \& HOPE, M. J. (1985). Physical properties and functional roles of lipids in membranes. In Biochemistry of Lipids and Membranes, pp. 25-72. Edited by D. E. Vance \& J. E. Vance. Menlo Park, California: Benjamin/Cummings Publishing Co.

DAHL, C. E., DAHL, J. S. \& BLOCH, K. (1980). Effect of alkylsubstituted precursors of cholesterol on artificial and natural membranes and on the viability of Mycoplasma capricolum. Biochemistry 19, 1462-1467.

Davey, J. F. \& MitTon, J. R. (1973). Cytochromes of two methaneutilizing bacteria. FEBS Letters 37, 335-337.

DAVIES, S. L. \& WhitTEnbuRY, R. (1970). Fine structure of methane and other hydrocarbon-utilizing bacteria. Journal of General Microbi$\operatorname{ology}$ 61, 227-232.

DeBoER, W. E. \& HAzeu, W. (1972). Observations on the fine structure of a methane-oxidizing bacterium. Antonie van Leeuwenhoek 38, 33-47.

DitTmer, J. C. \& Wells, M. A. (1969). Quantitative and qualitative analysis of lipids and lipid components. Methods in Enzymology 14, 482-530. 
Ghosh, R. \& Quayle, J. R. (1981). Purification and properties of methanol dehydrogenase from Methylophilus methylotrophus. Biochemical Journal 199, 245-250.

HANCOCK, I. C. \& Williams, K. M. (1986). The outer membrane of Methylobacterium organophilum. Journal of General Microbiology 132 , 599-610.

Hyder, S. L., Meyers, A. \& CAYer, M. L. (1979). Membrane modulation in a methylotrophic bacterium Methylococcus capsulatus (Texas) as a function of growth substrate. Tissue and Cell 11, 597610.

Ishidate, K., Creeger, E. S., Zrike, J., Deb, S., Glauner, B., MACAlister, T. J. \& ROTHFIELD, L. I. (1986). Isolation of differentiated membrane domains from Escherichia coli and Salmonella typhimurium, including a fraction containing attachment sites between the inner and outer membranes and the murein skeleton of the cell envelope. Journal of Biological Chemistry 261, 428-443.

JAHNKE, L. L. \& NichOLS, P. D. (1986). Methyl sterol and cyclopropane fatty acid composition of Methylococcus capsulatus grown at low oxygen tensions. Journal of Bacteriology 167, 238-242.

Karkhanis, Y. D., Zeltner, J. Y., Jackson, J. J. \& Carlo, D. J. (1978). A new and improved microassay to determine 2-keto-3deoxyoctonate in lipopolysaccharide of Gram-negative bacteria. Analytical Biochemistry 85, 595-601.

KATES, M. (1986). Techniques of lipidology: isolation, analysis and identification of lipids. In Laboratory Techniques in Biochemistry and Molecular Biology, vol. 3. Edited by R. H. Burbon \& P. H. van Knippenberg. Amsterdam: Elsevier.

LAEMmLI, U. K. (1970). Cleavage of structural proteins during the assembly of the head of bacteriophage T4. Nature, London 227, 680685 .

MacAlister, T. J., Macdonald, B. \& Rothfield, L. I. (1983). The periseptal annulus: an organelle associated with cell division in gram-negative bacteria. Proceedings of the National Academy of Sciences of the United States of America 80, 1372-1376.

MCDoNALD, K. (1984). Osmium ferricyanide fixation improves microfilament preservation and membrane visualization in a variety of animal cell types. Journal of Ultrastructure Research 86, 107118.

Makula, R. A. (1978). Phospholipid composition of methane-utilizing bacteria. Journal of Bacteriology 134, 771-777.

Monosov, E. Z. \& Netrusov, A. I. (1976). Localization of energy generators in methane-oxidizing bacteria. Microbiology 45, 518523.

NeUNList, S. \& RohmeR, M. (1985). Novel hopanoids from the methylotrophic bacteria Methylococcus capsulatus and Methylomonas methanica. Biochemical Journal 231, 635-639.

Nichols, P. D., Smith, G. A., ANTworth, C. P., Hanson, R. S. \& WHITE, D. W. (1985). Phospholipid and lipopolysaccharide normal and hydroxy fatty acids as potential signatures for methaneoxidizing bacteria. FEMS Microbiology Ecology 31, 327-335.

Nichols, P. D., Mancuso, C. A. \& White, D. C. (1987). Measurement of methanotroph and methanogen signature phospholipids for use in assessment of biomass and community structure in model systems. Organic Geochemistry 11, 451-461.

O'Brien, J. S. \& Rouser, G. (1964). Analysis of hydroxy fatty acids by gas-liquid chromatography. Analytical Biochemistry 7, 288-296.

ORNDORFF, P. E. \& DwORKIN, M. (1980). Separation and properties of the cytoplasmic and outer membranes of vegetative cells of Myxococcus xanthus. Journal of Bacteriology 141, 914-927.
Osborn, M. J., Gander, J. E., Paris, E. \& Carson, J. (1972). Mechanism of assembly of the outer membrane of Salmonella typhimurium. Journal of Biological Chemistry 247, 3962-3972.

Ourisson, G., Rohmer, M. \& Poralla, K. (1987). Prokaryotic hopanoids and other polyterpenoid sterol surrogates. Annual Review of Microbiology 41, 301-333.

Patel, R. N. \& Felix, A. (1976). Microbial oxidation of methane and methanol: crystallization and properties of methanol dehydrogenase from Methylosinus sporium. Journal of Bacteriology 128, 413-424.

PrioR, S. D. \& Dalton, H. (1985). The effect of copper ions on membrane content and methane monooxygenase activity in methanol-grown cells of Methylococcus capsulatus (Bath). Journal of General Microbiology 131, 155-163.

RoHMER, M., BOUVIER, P. \& OURisson, G. (1979). Molecular evolution of biomembranes: structural equivalents and phylogenetic precursors of sterols. Proceedings of the National Academy of Sciences of the United States of America 76, 847-851.

RoHmer, M., Bouvier, P. \& Ourisson, G. (1980). Non-specific lanosterol and hopanoid biosynthesis by a cell-free system from the bacterium Methylococcus capsulatus. European Journal of Biochemistry 112, 557-560.

RoHMer, M., Bouvier-Nave, P. \& OURisson, G. (1984). Distribution of hopanoid triterpenes in prokaryotes. Journal of General Microbiology 130, 1137-1150.

Saralov, A. I., Krylova, I. N., Saralova, E. E. \& Kuznetsov, S. I. (1985). Distribution and species composition of methane-oxidizing bacteria in lake waters. Microbiology 53, 695-700.

Schnartman, C. A. (1970). Examination of the protein composition of the cell envelope of Escherichia coli by polyacrylamide gel electrophoresis. Journal of Bacteriology 104, 882-889.

ScotT, C. C. L., Makula, R. A. \& FinNerTy, W. R. (1976). Isolation and purification of membranes from a hydrocarbon-oxidizing Acinetobacter sp. Journal of Bacteriology 127, 469-480.

Smith, P. K., Krohn, R. I., Hermanson, G. T., Mallia, A. K., Gartner, F. H., Provenzano, M. D., Fujimoto, E. K., Goeker, N. M., OLSON, B. J. \& KLENK, D. C. (1985). Measurement of protein using bicinchoninic acid. Analytical Biochemistry 150, 76-85.

Summons, R. E. \& JAHNKE, L. L. (1992). Hopenes and hopanes methylated in ring-A: Correlation of the hopanoids from extant methylotrophic bacteria with their fossil analogues. In Biological Markers in Sediments and Petroleum, pp. 182-200. Edited by M. Moldowan. Englewood Cliffs, NJ: Prentice Hall.

Thomas, D. S., Hossack, J. A. \& Rose, A. H. (1978). Plasmamembrane lipid composition and ethanol tolerance in Saccharomyces cerevisiae. Archives for Microbiology 117, 239-245.

Tonge, G. M., Knowles, C. J., Harrison, D. E. F. \& Higgins, I. J. (1974). Metabolism of one carbon compounds: cytochromes of methane- and methanol-utilizing bacteria. FEBS Letters 44, 106110 .

WADZINSKI, A. M. \& RibBons, D. W. (1975). Oxidation of $\mathrm{C}_{1}$ compounds by particulate fractions from Methylococcus capsulatus: properties of methanol oxidase and methanol dehydrogenase. Journal of Bacteriology 122, 1364-1374

White, D. C., Davis, W. M., Nickels, J. S., King, J. D. \& Bobbie, R. J. (1979). Determination of the sedimentary microbial biomass by extractable lipid phosphate. Oecologia 40, 51-62

WooD, P. M. (1984). Bacterial proteins with CO-binding $b$ - or $c$-type haem functions and absorption spectroscopy. Biochimica et Biophysica Acta 768, 293-317. 